\title{
Improving Students' Achievement in Speaking Monologue Text by Using Video
}

\author{
Masitowarni Siregar ${ }^{1}$, Ratna Eswarny ${ }^{2}$ \\ ${ }^{1}$ English Department, FBS Universitas Negeri Medan, Medan, Indonesia \\ ${ }^{2}$ SMPN 29 Medan Indonesia \\ siregarmasitowarni@yahoo.com
}

\begin{abstract}
This study aimed at increasing grade VII students' achievement in speaking monologue text by using media for English in SMP Negeri 29 Medan, Indonesia. Video as learning media needs to be used to increase students' speaking skills. The method of research used was Classroom Action Research (CAR). The research procedure included planning, implementation of actions, observation and reflection. The techniques used in this study were questionnaires, interviews, and observations. The data were analyzed by quantitative and qualitative techniques. Based on the results of the research and discussion, it can be concluded that the use of media could improve the quality of results and the learning process of English speaking aspects which increased the average students' score in the initial data was $57.7 \%$ to $58.31 \%$ (cycle I) and increased to $65.78 \%$ (cycle II), the average score of classical completeness also increased from the original $15.6 \%$ (initial data) to $37.5 \%$ (cycle II) and $81.25 \%$ (cycle II). Then, fluency was the highest increasing in improving the students' speaking ability which was 0,29 from cycle I to cycle II.
\end{abstract}

Keywords

monologue speaking; introducing self; video

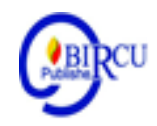

\section{Introduction}

In Indonesia English is learned in order to be able to communicate orally and in writing in international context.The Communication is intended to reveal news, thoughts, feelings and the development of sciencw, technology, and culture using the language. Communicate verbally and in writing by using a variety of languages that are in accordance smoothly and accurately. The mastery of communication skills means the ability to speak, namely the ability to interprate and or convey oral and or written texts that are implemented in four language skills, namely listening, speaking, reading and writing. The skills mentioned are utilized to respond or create commjunication in the society. In this sense the teaching of English are focused to develop the four skills of listening, speaking, reading and writing in English.

Teaching English covered teaching the four language skills; they are Listening, Speaking, Writing, and Reading. Reading is one language skills that should be mastered by students to become skillful person in the world because by reading, they can get more information from every side of the world. So, teachers should give their heart on how to improve students' achievement in reading comprehension and do not let the students just read the text as they know. As stated by Klingner in Sipayung (2018), knowing how to read, or decode, words is not a small part of the reading process; it is a critical link whose absence inhibits understanding. When students are beginning to read, they may have difficulty

Furthermore, in the 2013 English Curriculum Syllabus it was stated that the competencies expected after students learn English at the junior high school level were able to communicate in English. In detail, it is said that English subjects for junior secondary 
education aim to develop the potential of students to have communicative competencies in interpersonal, transactional, and functional texts, utilizing some kinds of oral and written English discourse. By utilizing these texts, it is expected that students are motivated to use factual, conceptual, and procedural knowledge and skills, and maintaining good values of national character, in the context of life in the home, school, and society.

With these objectives English has different characteristics from exact science or social science, which lies in the function of language as a communication tool. This means that learning English is not only learning vocabulary and grammar in the sense of knowledge, but

must try to apply and use it in daily activities as a means of communication (Hansen: 1984). In everyday life, people usually judge a person's English language skills from speaking ability. Someone who can smoothly convey ideas / ideas in English is said to be proficient in English (Ersoz, Aydan: 2000).

The ability to speak English in grade VII.1 SMPN 29 students from year to year is still low. The findings of researchers as English teachers in class VII.1 that focus on transactional interpersonal monologues that introduce themselves show that students are less confident and less competent in these competencies. The readiness of some students in learning is still relatively lacking so that the activity of some students in individual and group learning is still lacking. As a result of these problems students' speaking abilities were low, speaking scores were low and the test scores of most students in English still had not reached / exceeded the KKM of 65. This encouraged teachers to conduct classroom action research to find a solution.

After conducting discussions with the research team namely partner lecturers from Medan State University, it was found that the root of the problem was one of the lack of media used so far in learning English in the classroom. For this reason, as a research teacher, it is necessary to try to improve students' speaking skills by using video media. Video media are expected to improve verbal monologue communication to introduce themselves in English so that students' speaking skills in English can be improved.

With the background of the explanation above, the author conducted a study entitled " Improving Grade VII Students' Achievement in Speaking Monologue Text by Using Video Media SMP Negeri 29 Medan, Sumatera Utara Indonesia".

\section{Review of Literature}

\subsection{Students' Speaking Skill}

One focus of teaching English is the teaching of speaking skills in addition to the other three skills, namely, listening, reading and writing. Juhana (2012) emphasizes that the success of learning English is measured in the ability to carry out conversation using English. And according to Bahrani dan Soltani (2012) in general, the teaching of speaking skills in English is more emphasized in its linguistic system, especially teaching vocabulary and grammar compared to the practice of speaking. So, efforts need to be made to improve students' speaking abilities. In addition, in order to know the ability of someone in speaking, there are some elements that should be concerned such as pronunciation, accuracy, fluency, and intonation. Those aspects show how good the speaking itself in order that making the listeners to be easy to understand.

Djiwandono (2008) asserts that in teaching English four criteria of good pronunciation, should be maintained; intelligibility, fluency, accuracy and native-like. 
- Intelligibility means when speaking the utterance is clear and understandable as a part and as a whole context

- Fluency is the whole utterance is uttered within fluency.

- Accuracy is means pronouncing the whole or some of the text in a valid way. The speaker should speak native like.

Therefore, a good pronunciation will be influenced by those indicators that make the other people more understand what the speaker said.

When a foreigner speak English she should meet the qualification of the standard which is defined as Accuracy. Hence English intructors assume that speaking English in native like is the ideal target of teaching English in Indonesia.

Further, Fillmore (1979) asserts that speaking with high control of delivery rate is the indicator of fluency. A conversant should be able to bring along her idea in a consistent speed and comprehensible way. This is what Brumfit (1984) means as speaking in a foreign language the way native speakers speak.

\subsection{Video as Teaching Media}

Success in the learning process is obtained by a good process between students and teachers and the purpose of the learning itself can be delivered well by the teacher and processed or well received by students. Therefore, there needs to be a media that must be used in order to carry out learning well. Media is everything that can be used to channel messages from senders to recipients so that they can stimulate students' thoughts, feelings, concerns and interests in such a way that there is a learning process.

To help improve students' ability to speak there must be appropriate learning media and can make these students more interested in participating in the learning process. Because the media is one of the supporting factors that will make the learning process that takes place in the class goes well.

One of the best media used by teachers in the introducing self learning process to improve students' speaking skills is video media because the students can learn more effcectively and effiociently when the vidio is utilized during the instructional process. Videos are pictures in a frame where frame by frame is reflected through the in focus mechanically enabling the pictures to be seen alive. This tool is usually utilised for entertainment, documentation, and education. News, complex ideas and thouughts, series of actions, complicated norms and values expected behaviours could be projected by using videos.

To implement the use of video media in the learning process, researchers use procedures from Class Action Research (CAR). This research will be conducted using the existing stages in Classroom Action Research to be able to improve the ability of students to speak through the use of video media. And researchers conducted this study with the aim of improving students' speaking skills in introducing self-monologue text class VII 1 Medan 29 Middle School.

\subsection{Participant}

\section{Research Method}

This research was conducted in Medan Public Middle School 29 with 32 students in class VII 1. This research was conducted from August 2018 to October 2018.

\subsection{Instrument}

The data source in this study is the student scoring sheet in describing something through the use of video, the final test results in the form of oral tests in the form of 
interviews and observations made by researchers and students involved in the learning process. The data will be processed quantitatively and qualitatively.

\subsection{Procedure}

The research method used in this study is Classroom Action Research (CAR). This method uses the model Stephen Kemmis and Mc. Taggart (1998) adopted by Burns (2010: 89): This research was carried out using the following stages: (1) Planning; (2) Implementation of the action; (3) Observation; (4) Reflection. Researchers use this model because it is considered the most realistic and practical.

\subsection{Data Analysis Techniques}

In collecting data, researchers use observation and interview techniques. First, the researchers analyzed the data obtained from the observation sheets that had been obtained through observations to be able to describe the improvement in speech capabilities obtained by students through the use of video media. The researcher plans, implements actions, observes and reflects. In this study two cycles will be carried out using these stages. After that, the researchers calculated the presentation of students who exceeded the KKM and who did not exceed the KKM. Then comparing the percentage increase in students' speaking abilities starting from speaking grades, peer review sheets and final tests in the form of oral tests at the end of cycles I and II.

\section{Discussion}

The data used in this study consisted of qualitative data and quantitative data obtained from class VII 1 SMP Negeri 29 Medan through interviews, observation sheets and test sheets. In collecting data, researchers analyzed the situation and background through interviewing students, who were interviewed by the researcher was about the difficulties of students in mastering the ability to speak, after which compiled activities that would be carried out to improve students' speaking abilities. The subject of this research is class VII 1 SMP Negeri 29 Medan which consists of 32 students. This research was carried out using two cycles. Each cycle consists of 4 stages of action, namely Planning, action, observation and reflection. In the first cycle consists of test orientation and three meetings. While the second cycle consisted of two meetings.

\subsection{Quantitative Data}

Quantitative data is derived from the results of two cycles that have been carried out. In carrying out the two cycles, researchers examined in 5 meetings. Tests are given to students at the end of each cycle.

Table 1. The Score of Students' Speaking Skill

\begin{tabular}{llccc}
\hline No & $\begin{array}{c}\text { Students' } \\
\text { Name }\end{array}$ & Pra Cycle & Cycle 1 & Cycle 2 \\
\hline 1 & NW & 50 & 60 & 65 \\
\hline 2 & UI & 52 & 55 & 65 \\
\hline 3 & WI & 52 & 52 & 65 \\
\hline 5 & SS & 70 & 75 & 75 \\
\hline 6 & SE & 55 & 55 & 60 \\
\hline 7 & RJ & 60 & 65 & 65 \\
\hline
\end{tabular}




\begin{tabular}{llccc}
\hline 8 & VS & 60 & 65 & 65 \\
\hline 9 & GA & 50 & 50 & 55 \\
\hline 10 & IS & 52 & 60 & 65 \\
\hline 11 & IJ & 70 & 75 & 75 \\
\hline 12 & GH & 55 & 55 & 65 \\
\hline 13 & DF & 55 & 55 & 70 \\
\hline 14 & BS & 50 & 50 & 60 \\
\hline 15 & WS & 60 & 65 & 70 \\
\hline 16 & BS & 60 & 70 & 75 \\
\hline 17 & EN & 70 & 75 & 75 \\
\hline 18 & AM & 70 & 70 & 75 \\
\hline 19 & FY & 60 & 65 & 70 \\
\hline 20 & DO & 60 & 60 & 65 \\
\hline 21 & NT & 70 & 70 & 70 \\
\hline 22 & ML & 50 & 50 & 60 \\
\hline 23 & RT & 55 & 55 & 65 \\
\hline 24 & LS & 50 & 50 & 65 \\
\hline 25 & ES & 50 & 55 & 60 \\
\hline 26 & GP & 50 & 50 & 65 \\
\hline 27 & DP & 50 & 50 & 60 \\
\hline 28 & LK & 55 & 60 & 70 \\
\hline 29 & SR & 60 & 65 & 70 \\
\hline 30 & EO & 60 & 65 & 70 \\
\hline 31 & SM & 55 & 65 & 65 \\
\hline 32 & NH & 60 & 70 & 70 \\
\hline & Total & 1776 & 1882 & 2070 \\
\hline & Average & 55.5 & 58,81 & 64,68 \\
\hline & & & & \\
\hline & & & & \\
\hline
\end{tabular}

Qualitative data is obtained from the interaction between students and teachers in the classroom when the teaching learning process takes place, while the student performance sheets are assisted by structured observation sheets. And researchers fill in the observation sheet that has been provided to be filled during the observation process in the classroom. Data also obtained from interviews conducted at the first meeting and pre-cycle found that students' problems in speaking were the lack of motivation of students to try and follow the learning process, when testing was conducted directly with students, the students had difficulty doing questions and answers using English and supported by the acquisition of student grades that can still be categorized as low.

\subsection{Data Analysis}

Obtaining increased student grades begins obtained on cycle II. The researcher gave a test directly at the end of each cycles. During the study, it was found that the value of students always increased at each meeting. The value of students in cycle I was higher than the value of students in pre- cycle and the value of students in cycle II was also higher than the cycle I. Increasing the value of students always occurred starting from pre-cycle to cycle II. This could be seen in the following table. 
Table 2. Students' Score Improvement

\begin{tabular}{|c|c|c|}
\hline No. & $\begin{array}{c}\text { Students Who Get Value } \\
\text { Enhancements }\end{array}$ & Score \\
\hline & NW & $50-65$ \\
\hline & UI & $52-65$ \\
\hline & WI & $52-65$ \\
\hline & WG & $65-70$ \\
\hline & SS & $50-55$ \\
\hline & $\mathrm{SE}$ & $55-65$ \\
\hline & GA & $50-55$ \\
\hline & IS & $52-60$ \\
\hline & IJ & $70-75$ \\
\hline & $\mathrm{GH}$ & $55-65$ \\
\hline & DF & $55-70$ \\
\hline & $\mathrm{BS}$ & $50-60$ \\
\hline & $\mathrm{BS}$ & $60-65$ \\
\hline & FY & $65-70$ \\
\hline & DO & $60-65$ \\
\hline & ML & $50-60$ \\
\hline & RT & $55-65$ \\
\hline & $\mathrm{LS}$ & $50-65$ \\
\hline & $\mathrm{ES}$ & $50-60$ \\
\hline & GP & $50-65$ \\
\hline & DP & $50-70$ \\
\hline & LK & $55-70$ \\
\hline & SR & $60-70$ \\
\hline & EO & $65-70$ \\
\hline & SM & $65-70$ \\
\hline
\end{tabular}

Increasing the value of students' speaking abilities in learning using video media can be seen from the average score of students during the study. In searching for the average value of students, researchers use formulas

$$
\mathrm{X}=\frac{\sum x}{N} \times 100 \%
$$

$X$ : average student

$\sum \mathrm{x}$ : Total value

$\mathrm{N}$ : Number of students

In the pre-cycle, the total number of student scores was 1851 and students numbered 32. So, the average student was $\mathrm{X}=\frac{1851}{32}=57,8$

In the first cycle, the total number of student grades was 1876 and the number of students was 32 . So, the average score of students was $X=\frac{1876}{32}=58,62$

In cycle II, the total number of student grades is 2045 and the number of students is 32 . So, the average score of students is $\mathrm{X}=\frac{2045}{32}=67,78$

The average score of students at the end of the cycle is high, so it can be said that the achievement of students' speaking abilities using video media increased from $57.8 \%$ to 
$67.78 \%$. The number of students who master and exceed $\mathrm{KKM}$ is calculated using the formula: $\mathrm{P}=\frac{R}{T} \times 100 \%$

Where: $\mathrm{P}=$ percentage of students who exceed KKM

$\mathrm{R}=$ number of students who do not exceed the KKM

$\mathrm{T}=$ Total students taking the test

The percentage increase in student achievement can be seen as follows:

1. $\mathrm{P} 1 \mathrm{~A} \frac{5}{32} \times 100 \%=15,62 \%$

2. $\mathrm{P} 2 \mathrm{~A} \frac{12}{32} \times 100 \%=37,5 \%$

3. $\mathrm{P} 3 \mathrm{~A}_{32}^{\frac{26}{32}} \times 100 \%=81,25 \%$

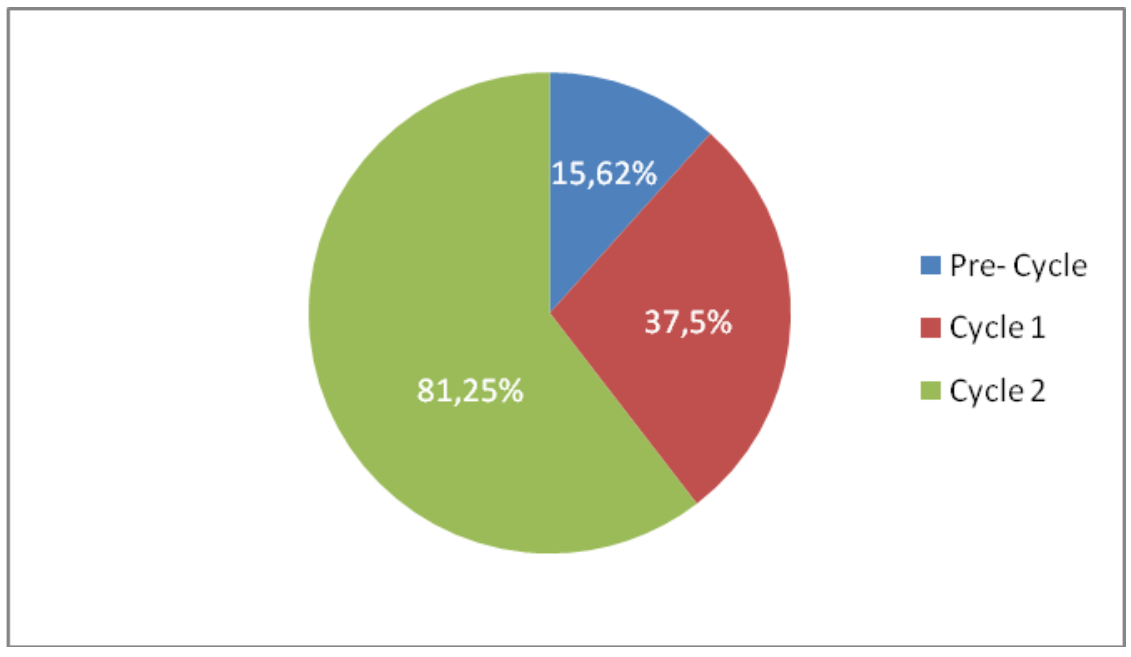

Figure 1. Research Cycles

Figure 1 shows an increase in students' speaking ability achievement from pre-cycle to cycle II. In the pre-cycle only $15.62 \%$ of students could reach KKM. In the first cycle there were $37.5 \%$ of students who reached the KKM, meaning there was an increase of around $21.88 \%$. When the second cycle finished there were $81.25 \%$ of students who reached KKM. When the second cycle done, only six students did not reach KKM but their scores from pre-cycle to cycle II continued to increase. Therefore, this can mean that in the text monologue learning process Introducing self by using video media can improve students' speaking abilities.

In addition, in making the score of the students, the teacher had already concerned with the elements supporting the speaking itself which are pronunciation, fluency, accuracy, and intonation of the speakers. The mean of Each Elements score in cycle I and II is showed in table below.

Table 3. The Mean of Elements Score in Cycle I and II

\begin{tabular}{llccc}
\hline No & Element & Cycle I & Cycle II & Range of Cycle I and II \\
\hline 1 & Pronunciation & 3,97 & 4,24 & 0,26 \\
\hline 2 & Fluency & 3,35 & 3,65 & 0,29 \\
\hline
\end{tabular}




\begin{tabular}{lllll}
\hline 3 & Accuracy & 3,47 & 3,62 & 0,15 \\
\hline 4 & Intonation & 3,88 & 4,00 & 0,12 \\
\hline
\end{tabular}

Based on table 3 it can be concluded that there was increasing between cycle I and II in speaking ability through use of video media. It means that, the media influence the students to more confidence and to know how speak well. Since they had known and seen the example how to introduce themselves by using monologue text through the video itself that make them more enthusiastic. In addition, based on the table above, the element that give the most improving significantly showed in diagram below.

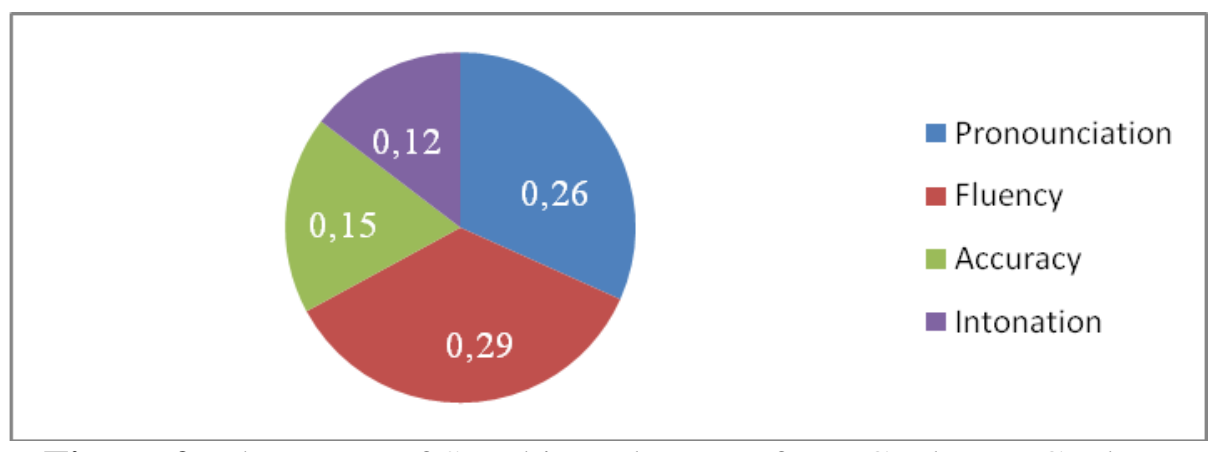

Figure 2. The Mean of Speaking Elements from Cycle I to Cycle II

Based on figure 2, fluency is the highest mean since through the video, the students were easy to train their ability in speaking since they would see the interesting example. Then, in improving fluency, training is as the best way.

\section{Conclusion}

Learning videos are one of the media that have audio (sound) and visual motion (moving images) elements. As a learning media, video acts as an introduction to information from the teacher to students. The ease of repeating videos (replays) and how to present information structurally makes video one of the media that can enhance students' ability to understand a concept. Based on the results of the research and discussion the researchers made the conclusion: the use of video media can improve the ability to speak in Introducing self-text monologues in Medan 29 Public Senior High School class VII 1 which was built with the teacher easily repeating video playback so that it was easier for students to imitate the models in the video experiencing some modifications and adjustments to the learning objectives, it has been proven to be able to improve the quality of results and the learning process of the English language speaking aspect which includes an increase in the average grade of classical completeness in the initial data by $15 \%$ to $57.8 \%$ (cycle I) and increase again to $67,78 \%$ (cycle II).

In addition, the results of the research was also influenced by the speaking elements such as pronunciation, fluency, accuracy, and intonation. Fluency is the highest mean from cycle I to cycle II since through the video, the students were easy to train their ability in speaking since they would see the interesting example. Then, in improving fluency, training is as the best way. 


\section{References}

Burns, Anne. (2010). Doing Action Research in English Language Teaching; A Guide for Practitioners. First Edition.New York and London: Routledge Taylor \& Francis Group.

Dirjen Dikdasmen, 2007, Kurikulum Sekolah Menengah Pertama Bertaraf Internasional Mata Pelajaran Bahasa Inggris, Jakarta

Fillmore, C. J. (1979). On fluency. In D. Kempler \& W. S. Y. Wang (Eds.), Individual differences in language ability and language behavior (pp. 85-102). New York: Academic Press.

Nurhadi. (2016). Peningkatan Kompetensi Speaking Monolog Procedure Text Melalui Metode Tpr Plus Speaking Pada Siswa Smp Kelas Ix ://jurnal.fkip.uns.ac.id/index.php/paedagogia

Suganda, Agus.,et al. (2008). Upaya Meningkatkan Kemampuan Bicara Siswa Dalam Bahasa Inggris Melalui Permainan Snake And Ladder Di Kelas Vii-A Smp Negeri 1 Cimahi.

Supryadi, P. E., et al. (2013). Penerapan Media Video Pembelajaran sebagai Aplikasi Pendekatan Contekstual Teaching Learning untuk Meningkatkan Hasil Belajar IPA Siswa Kelas V. Mimbar PGSD, (Online), 1 (1),

Susilo. (2007). Penelitian Tindakan Kelas, Yogyakarta

Wachidah, Siti. (2014). When English Rings a Bell: buku guru, Kementrian Pendidikan dan Kebudayaan: Jakarta

Yingjie, Yang. (2014). The development of speaking fluency: The 4/3/2 technique for the EFL learners in China. International Journal of Research Studies in Language Learning. Vol. 3 Pages: 55-70

(http://ejournal.undiksha.ac.id/index.php/JJPGSD/article/view/1492),14 April 2017 